\title{
Comparative analysis of the use of space in 7-a-side and 8-a-side soccer: how to determine minimum sample size in observational methodology
}

\author{
Análise comparativa da utilização do espaço de jogo em Futebol-7 e \\ Futebol-8: aplicação da Metodologia Observacional para a determinação do \\ tamanho mínimo da amostra
}

Daniel Lapresa ${ }^{1}$, Ildefonso Álvarez², Maria Teresa Anguera ${ }^{3}$, Javier Arana ${ }^{4}$, Belén Garzón ${ }^{1}$ ORIGINAL ARTICLE | ARTIGO ORIGINAL

\begin{abstract}
In 2011-2012, the Spanish Soccer Federation changed the format of junior championship matches played between regional-level teams in Spain from a 7-a-side to an 8-a-side format. Soon afterwards, the regional federations followed in their footsteps by adapting their competition formats accordingly. Taking the use of space as a functional indicator of the quality of play in U-10 soccer, the present study examines the relative suitability of the 7-a-side and 8-a-side formats for developing the skills of young players. Of 9 hypothesis contrasts relating to the zone in which a move initiated in the attacking team's goal area ended, only one was significant $(\mathrm{p}<.05)$ in the standard analysis, even though the contingency tables suggested there were genuine differences between the two formats studied. Consequently, the statistical software program GPower was used to determine the minimum sample size necessary to detect significant differences for four levels of statistical power: $95 \%, 90 \%, 85 \%$, and $80 \%$. Given the difficulty of organizing a new round of data collection, we simulated an increase in sample size while maintaining the characteristics of the original data (frequencies, variability, and distribution). The results obtained through the original sampling were then compared with those from the simulation.

Keywords: observational methodology, sample size, statistical power, soccer.
\end{abstract}

RESUMO

No decorrer da época desportiva 2011-2012, a Federação Espanhola de Futebol alterou o formato das competições de jovens nos jogos realizados entre as equipas representativas das diferentes regiões autónomas de Espanha. No sentido de respeitar as normas instituídas, as federações regionais adaptaram as respetivas competições. Considerando-se a utilização do espaço como um indicador funcional da qualidade de jogo neste nível, o presente estudo examina a adequação dos dois formatos: Futebol-7 e Futebol-8. De entre as nove hipóteses encontradas acerca da relação entre a zona em que a situação de jogo se iniciava e que, posteriormente, terminava, apenas uma hipótese se mostrou significativa $(\mathrm{p}<.05)$. Não obstante, as tabelas de contingência evidenciaram diferenças significativas entre a situação de jogo reduzido de $7 \times 7$ e $8 \times 8$. Utilizou-se o software estatístico G-Power para determinar o tamanho mínimo da amostra que, provavelmente, permitiria encontrar diferenças significativas nos diferentes níveis de potência do teste: $95 \%, 90 \%, 85 \%$, e $80 \%$. Dadas as dificuldades em organizar uma nova recolha de dados, simulou-se o aumento do tamanho da amostra respeitando-se as características dos dados originais, nomeadamente os valores encontrados, a variabilidade e a distribuição. Os resultados obtidos através da amostra original foram, posteriormente, comparados com os resultados da simulação.

Palavras-chave: metodologia observacional, tamanho da amostra, potência do teste, futebol.

Manuscript received July 10 ${ }^{\text {th }}$, 2014; Accepted March 27 th 2015

${ }^{1}$ University of La Rioja, Spain

${ }^{2}$ Isabel I University, Spain

${ }^{3}$ University of Barcelona, Spain

${ }^{4}$ International University of La Rioja (UNIR), Spain

* Corresponding author. Edificio Vives. C/ Luis de Ulloa s/n. 26007. Logroño (La Rioja). E-mail: daniel.lapresa@unirioja.es 


\section{INTRODUCTION}

Competition formats in grassroots soccer influence not only the educational opportunities associated with the practice of sport, but also the preparation of future soccer players in terms of physical and psychological development and acquisition of skills and tactical knowledge (Lapresa, 2009). Modifications to standard game formats through variations in player numbers and pitch size influence children's ability to perform technical-tactical tasks both efficiently and effectively (Castelo, 2009; Lapresa, Arana, Garzón, Egüen, \& Amatria, 2008; Vegas, 2006). Scientific studies justifying the competition formats designed by sports institutions are therefore necessary (Arana, 2011; Arana, Lapresa, Anguera, \& Garzón, 2012; Ardá, 1998; Ardá \& Anguera, 2000; Etxeazarra, 2014; Lapresa, Arana, Anguera, \& Garzón, 2013).

The Spanish Soccer Federation (RFEF) is made up of 19 regional federations, responsible for organizing competitions within each of Spain's regions, or autonomous communities. The RFEF also organizes junior championship matches between these regions. In 2011-2012, the RFEF changed the game format in the U-12 age group (ages 10-12) from 7-a-side to 8-a-side. The regional federations followed suit, believing that by adopting the format used at the national level, their teams would be better equipped to compete against other regional sides in the shortto-medium term.

Supporters of the 8-a-side game format, such as Meléndez (2001, 2010) and Wein (2006), argue that this format produces a more balanced distribution of players on the pitch (Figure 1), although it is also possible that this more balanced model could make it more difficult for U-12 players to build successful attacks. It has been argued that the greater imbalance created by the 7 -a-side format and the consequent ease of opening up spaces on the pitch could be more conducive to the development of technical skills in young players (Federazione Italiana Giuoco Calcio, 2008; Wein, 2006). Furthermore, as noted by Ardá (1998) and Lapresa (2009), the 7a-side format offers, from both a technical and tactical perspective, a potentially greater range of

playing positions and consequently more opportunities for fostering the development of players at this level.

7-A-SIDE

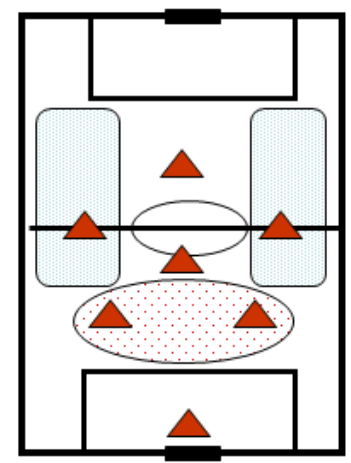

Figure 1. Most common tactical formations used in the 7-a-side format (1-2-3-1) and 8-a-side format (1-3$3-1)$. The shaded areas on the 7 -a-side pitch indicate zones that are most likely to be affected by its less balanced formation. Adapted from Meléndez (2010).

This study had two distinct yet related aims. The first was to, using observational methodology, examine differences in the use of pitch space by attacking teams in 7-a-side and 8a-side soccer by considering the start and end spatial locations of the offensive sequence of play along with the ball path. The analysis focused on moves that begin in the goal area of the team being observed, as these provide a good measure of a team's ability to move the ball up the pitch. Castellano (2000) and Perea (2008) describe the difficulties of reaching the rival goal area when a move begins deep in one's own defense, and using sequential analyses, Castellano (2000) illustrated that as play moves closer to the opponent's goal, the space behind becomes less defined, while that ahead becomes increasingly delimited.

The second aim of our study was to calculate the minimum sample size required to detect statistical differences in the use of pitch space between the 7-a-side and 8-a-side formats. Increasing sample size (without altering significance level or effect size) increases the chances of detecting significant differences between study groups. In other words, it increases the statistical power of the study. As stated by Dupont and Plummer (1990) and 
Ninín, Villalón, Terrasa, and Rubinstein (2007) it helps to think of sample size as a lens through which differences can be examined. While a small sample can reduce the chances of detecting true differences, an overly large simple size can uncover insignificant details. Minimum sample size calculation is an inherent part of many studies and requires a methodologically sound analysis, particularly in observational methodology studies such as the present one, where it is not uncommon to suspect that the sample size was not large enough to detect significant differences. While large-scale observational sampling may be desirable, it can require an excessive use of valuable resources (Kerlinger \& Lee, 2001).

\section{METHOD}

For the purpose of the present observational study, we organized two triangular tournaments (7-a-side and 8-a-side) between three soccer teams about to move up from the U-10 age group to the U-12 age group. Each team played two matches ( $A$ vs $B, B$ vs $C$, and $A$ vs $C$ ) in each of the tournaments. The study design was point (no within- or between-session follow-up), nomothetic (observation of three teams), and unidimensional (focus on the use of space) (Anguera, Blanco-Villaseñor, Hernández-Mendo, \& Losada, 2011; Blanco-Villaseñor, Losada, \& Anguera, 2001). It was also non-participatory (no interaction between observers and observees) and active, as it sought to fulfill the criterion of scientific rigor and relied fully on the observer's perception (direct observation). The study was approved by a scientific committee at the University of La Rioja and conducted in accordance with the Ethical Principles of Psychologists and Code of Conduct of the American Psychological Association and the guidelines of the Ethics Committee of the Spanish Association of Psychologists.

\section{Participants}

The participants were members of the three top-ranking soccer teams that took part in the U10 5-a-side league organized by the regional soccer federation in La Rioja, Spain. 5-a-side soccer in this age group is played using the same pitch and ball as that used in adult futsal. The children had never played an official 7-a-side game, and had no experience of 8-a-side soccer, as this format had not yet been introduced in the region at the time of the tournament.

\section{Observation instrument}

Table 1 shows the observation instrument created for the study. The instrument was designed to analyze the movement of a ball up a soccer pitch (Santos et al., 2009; Sarmento, Leitão, Anguera, \& Campaniço, 2009) and combined a field format system, used to analyze the movement of the ball through the different zones of the pitch (criterion 5), and a category system consisting of five exhaustive and mutually exclusive categories (criteria 1,2,3,4,6).

Table 1.

Structure of the observation instrument.

\begin{tabular}{|c|c|c|c|c|}
\hline No. & Criterion & $\begin{array}{l}\text { Type of } \\
\text { criterion }\end{array}$ & $\begin{array}{l}\text { Category Field } \\
\text { System format }\end{array}$ & Brief description: codes \\
\hline 1 & Game format & Fixed & $\mathrm{X}$ & 7-a-side; 8-a-side \\
\hline 2 & Ball possession & Fixed & $\mathrm{X}$ & $\begin{array}{l}\text { Observed team; Rival team; Not } \\
\text { observable }\end{array}$ \\
\hline 3 & Zone in which move starts & Variable & $\mathrm{X}$ & $\begin{array}{l}\text { ZS10, ZS20, ZS30, ZS40, ZS50, ZS60, } \\
\text { ZS70, ZS80, ZS90 }\end{array}$ \\
\hline 4 & Zone in which move ends & Variable & $\mathrm{X}$ & $\begin{array}{l}\text { ZE10, ZE20, ZE30, ZE40, ZE50, } \\
\text { ZE60, ZE70, ZE80, ZE90 }\end{array}$ \\
\hline 5 & $\begin{array}{l}\text { Zone(s) through which the move } \\
\text { develops }\end{array}$ & Variable & $\mathrm{X}$ & $\begin{array}{l}\text { The path followed by the ball through } \\
\text { the different zones of the pitch (ZD) } \\
\text { from the start to the end of the move }\end{array}$ \\
\hline 6 & $\begin{array}{l}\text { Zone in which there is a single contact } \\
\text { between the ball and a rival player }\end{array}$ & Variable & $\mathrm{X}$ & $\begin{array}{l}\text { ZIR10, ZIR20, ZIR30, ZIR40, ZIR50, } \\
\text { ZIR60, ZIR70, ZIR80, ZIR90 }\end{array}$ \\
\hline
\end{tabular}

Figures 2-6 show the nine zones into which the pitch was divided. Each zone had the same dimensions: $13.33 \times 21 \mathrm{~m}$. In match analysis studies, it is standard practice to divide the pitch 
into corridors and sectors using imaginary lines (Ardá \& Anguera, 2000; Costa, Garganta, Greco, \& Mesquita, 2009; Perea, 2008; Vales, 1998). In addition to the nine zones, the pitch was divided into three transverse sectors (safety, creation, and definition) to analyze depth of play and three longitudinal strips (left, central, and right) to analyze breadth, or width, of play.

\section{Procedure}

The two tournaments were held at the end of the season, when the children were about to move from the 5-a-side U-10 format to the U-12 format. The 8-a-side tournament was played one week after the 7-a-side tournament. All the matches lasted 25 minutes, and as the first aim of the study was to analyze how game format (7a-side vs 8-a-side) influences the use of space in offensive play, the following parameters were kept constant across all matches: pitch size $(63 \mathrm{x}$ $40 \mathrm{~m}$ ), ball size (no. 4), use of a referee, match rules, players, use of a coach, and tactical formation (1-2-3-1 for 7-a-side games and 1-3-31 for 8 -a-side games).

The digital recordings of the matches were viewed using Windows Media Player. The datasets for all matches were generated using SDIS coding syntax in SDIS-GSEQ version 5.1, as described by Bakeman and Quera (1996). The data were sequential, event-based (type I) data (Bakeman, 1978).

The initial observational sample consisted of 340 moves for the 7 -a-side matches and 349 for the 8 -a-side matches. The final number of moves included in the data analysis (all those that started in zone 20-the zone containing the attacking team's goal) was 67 for the 7 -a-side format and 77 for the 8-a-side format.

The data were coded from the observation instrument by two observers. The first coded the entire observational sample, while the second coded just one match for each game format. The observers received prior training in the use of the observation instrument, whose simple design does not require familiarity with soccer or soccer terminology (see Anguera, 2003).

The reliability of the data generated was assessed by Cohen's kappa (Cohen, 1960), which is a measure of agreement between nominal classifications with distinct categories. The kappa statistic quantifies interobserver agreement after correcting for the level of agreement that would be expected by chance (von Eye \& von Eye, 2005). It was computed using SDIS-GSEQ 5.1. The fact that a similar number of moves was recorded in both the datasets used for this analysis (49 for the 7-a-side match and 51 for the 8-a-side match) ensured alignment and greatly facilitated calculations (Bakeman, Mcarthur, \& Quera, 1996; Quera, Bakeman, \& Gnisci, 2007). The level of interobserver agreement was $93 \%$ for the 7-a-side match (kappa $=.92$ ) and $94 \%$ (kappa $=.94)$ for the 8-a-side match, which based on the criteria proposed by Landis and Koch (1977, p. 165) can be considered "almost perfect".

\section{Data analysis}

Categorical variables were analyzed using Pearson's $\chi^{2}$ test of independence and Cramer's $\mathrm{V}$. The variables analyzed were the forward-most zones, sectors (safety, creation, and definition) and strips (left, central, and right) in which offensive moves initiated in zone 20 (attacking team's goal area) ended.

Discrepancies between expected and observed frequencies can be quantified by the $\chi^{2}$ statistic. The Pearson $\chi^{2}$ test is used when data are ordered according to a single classification criterion (Kerlinger \& Lee, 2001). The test indicates the two-tailed significance of the data, in other words, the probability of obtaining these data in the event that the null hypothesis is true. When $\mathrm{p}<.05$ the null hypothesis is rejected. It can then be concluded that: a) the variables tested are not independent of each other; $b$ ) the variables tested are significantly related to each other; or c) the observed or empirical frequencies $\left(f_{o}\right)$ are significantly different from the expected frequencies $\left(f_{e}\right)$, i.e., there are significant differences between the data for the groups compared.

Cramer's $\mathrm{V}$ is an extension of the phi correlation coefficient, although in this case, and in contrast to the coefficient of contingency, it is normalized (Martín, Cabero-Morán, \& de PazSantana, 2007). Cramer's V ranges between 0 and 1 , with values close to 0 indicating no 
association, and those close to 1 indicating strong association.

\section{Statistical analysis with a minimum sample size}

When a statistical hypothesis test yields a non-significant result, it is advisable to test the statistical power of each comparison by calculating the sample size that would be required to detect significant differences between groups. If the estimated sample is not excessively large, then revision of the empirical study should be considered. If, on the other hand, it is unreasonably large, it can be concluded that the study was conducted correctly and that the results are not statistically significant.

In the present study, the software program GPower 3.1.2 was used to estimate minimum sample size following the procedures described by Faul, Erdfelder, Lang, and Buchner (2007) and Faul, Erdfelder, Buchner, and Lang (2009). GPower enables users to specify certain values a priori and then computes the sample size required to achieve these. In this study the parameters specified were:

a) The probability of making a type I or $\alpha$ error, which indicates the maximum error we are prepared to accept when rejecting the null hypothesis of data equivalence. The general consensus in the scientific community is that this should be set at $5 \%(\mathrm{p}<.05)$.

b) The power or sensitivity of the test to detect significant results. This is defined by the probability $1-\beta$, where $\beta$ is the probability of wrongly not rejecting the alternative hypothesis. The value of $1-\beta$ depends on the type of study being conducted, but the most widely used values range between 0.80 and 0.95 , which correspond to a probability of between $80 \%$ and $95 \%$ of detecting significant differences.

c) Effect size, in other words, the standardized distance between the mean results obtained for two groups being compared. Its value depends on the data from the original sample.

d) Degrees of freedom of the test, which indicate the number of possibilities that the differences between the groups may be significant.
In order to calculate the minimum sample size for the present study the above parameters were specified as follows:

a) $\alpha$ (probability of type I error): $\mathrm{p}<.05$.

b) Probability of not committing a type II error, or $1-\beta=0.95$.

c) Effect size: calculated a priori by GPower using the observed frequencies in the original sample.

d) Degrees of freedom: 8 (we distinguished between nine groups, corresponding to each of the nine pitch zone, so $9-1=8$ ).

Once the values for the input parameters (above) and the output parameters (values or frequencies from original analysis plus variability and distribution) are entered, the software computes the necessary sample size for the powers specified.

\section{RESULTS}

Differences in the use of pitch space in the 7-aside and 8-a-side game formats

The first step involved a general analysis of the zones in which moves initiated in zone 20 ended. The hypothesis test applied to the contingency table zone ${ }^{*}$ format (figure 2) revealed no significant differences between the 7a-side and 8-a-side format (Pearson's $\chi 2=$ 10.227; $\mathrm{p}<.249$; d.f. $=8$; Cramer's V = .249).

In the general analysis by sector, the hypothesis test applied to the contingency table Sector ${ }^{*}$ Format (Figure 3) once again revealed no significant differences (Pearson's $\chi^{2}=1.650$; $\mathrm{p}<.438$; d.f. $=2$; Cramer's V $=0.107$ ).

The next step involved applying a more specific hypothesis test (by zone) to each of the three sectors (safety, creation, and definition). Figure 4 shows the combined results from the corresponding contingency tables. No significant differences were found between the two formats for any of the sectors: safety (Pearson's $\chi^{2}=$ 2.302; $\mathrm{p}<.316$; d.f. $=2$; Cramer's $\mathrm{V}=.392$ ), creation (Pearson's $\chi^{2}=4.232 ; \mathrm{p}<.121$; d.f. $=$ 2; Cramer's $\mathrm{V}=.224$ ), or definition (Pearson's $\chi^{2}=2.181 ; \mathrm{p}<.336 ;$ d.f. $=2$; Cramer's $\mathrm{V}=$ $.220)$. 


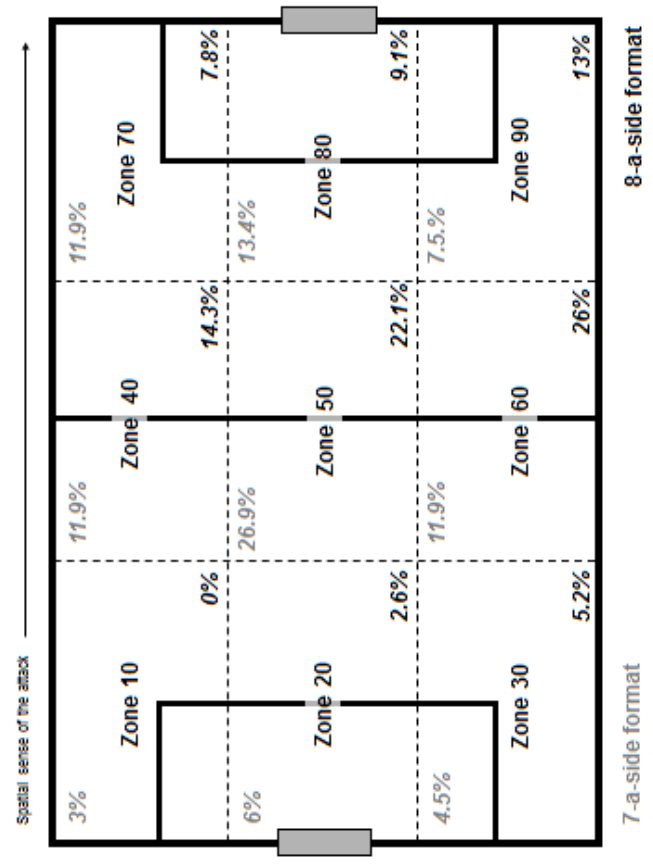

Figure 2. Results for the contingency table Zone * Format.

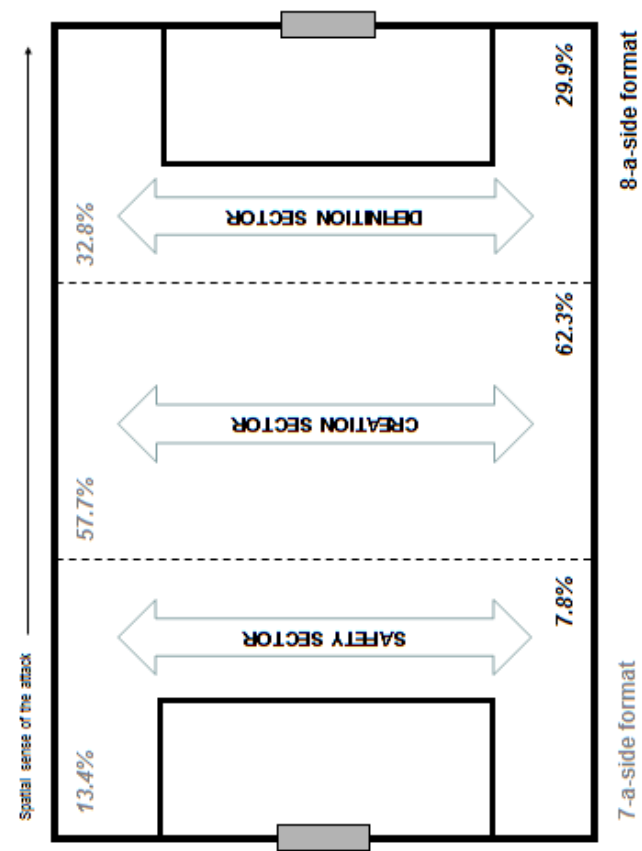

Figure 3. Results for the contingency table Sector * Format.

In the general analysis by longitudinal strip, the hypothesis test applied to the contingency table Strip * Format (Figure 5) revealed significant differences between the formats (Pearson's $\chi^{2}=6.677 ; \mathrm{p}<.035$; d.f. $=2$; Cramer's V $=.215$ ).

We then applied a more specific hypothesis test (by zone) to each of the three strips (left, central, and right). Figure 6 shows the combined results from the corresponding contingency tables, with no significant differences observed between the two formats for any of the strips analyzed: left (Pearson's $\chi^{2}=2.733 ; \mathrm{p}<.255$; d.f. $=2$; Cramer's $\mathrm{V}=.279$ ), central (Pearson's $\chi^{2}=$ .334; $\mathrm{p}<.846$; d.f. $=2$; Cramer's $\mathrm{V}=.075)$, or right (Pearson's $\chi^{2}=.543 ; \mathrm{p}<.762$; d.f. $=2$; Cramer's V $=.104)$.

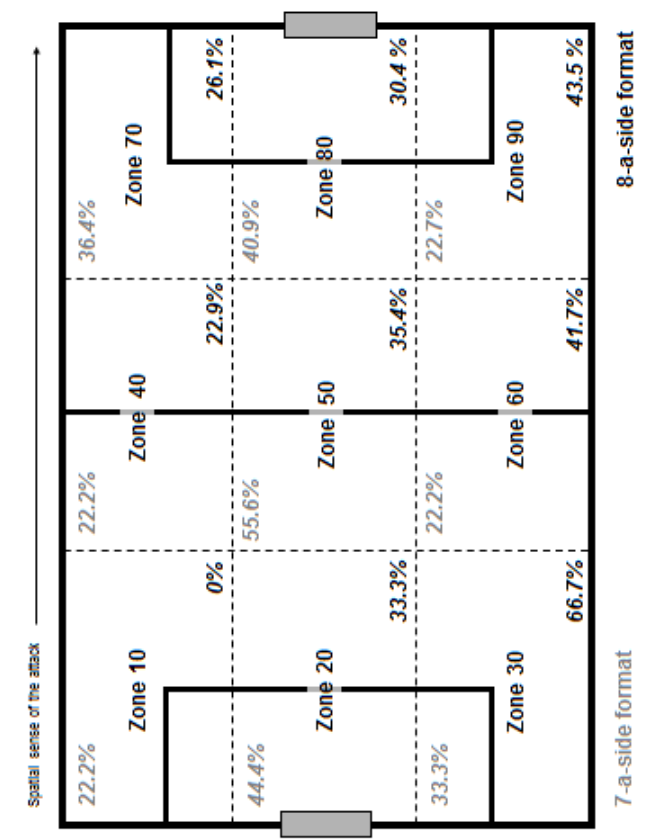

Figure 4. Combined results from the contingency tables for Format ${ }^{*}$ Sector (by zone) in which moves ended (i.e., safety, creation, and definition)

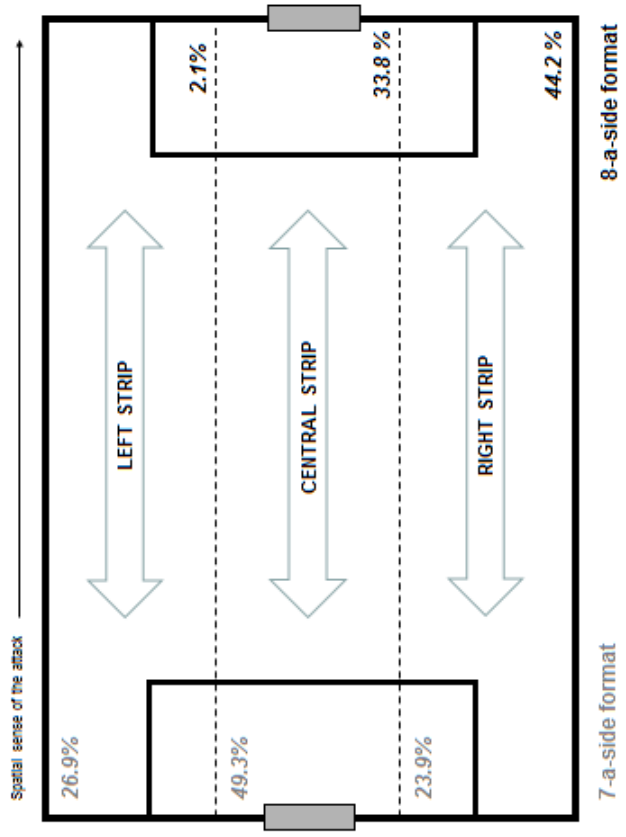

Figure 5. Results from the contingency table Strip * Format 


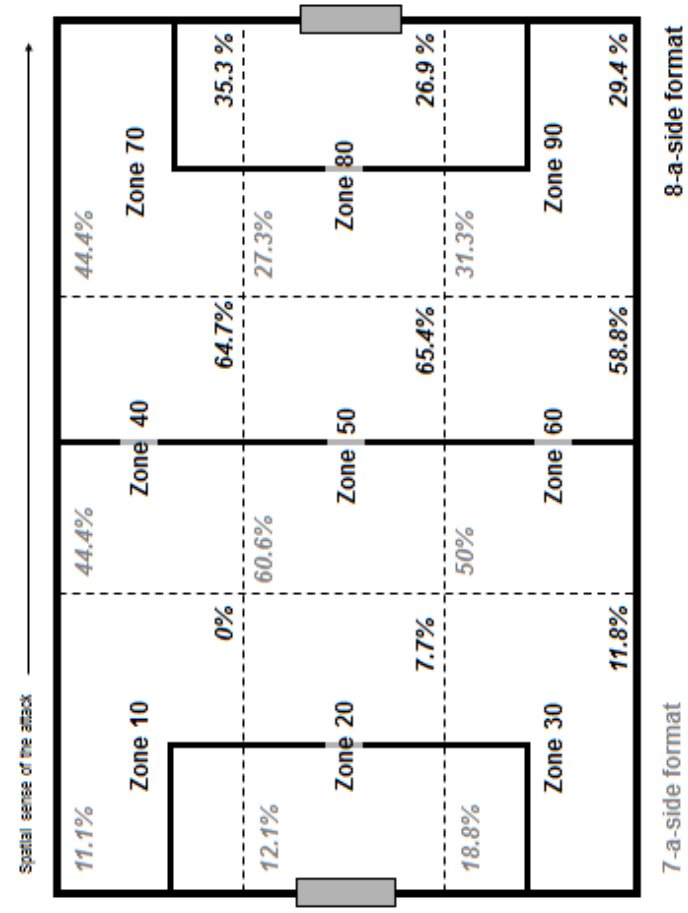

Figure 6. Combined results from the contingency tables for Format * Strip (by zone) in which moves ended (i.e., left, central, and right)

\section{Determination of minimum sample size for detecting significant differences}

In our analysis of the original data, significant differences between the 7-a-side and 8-a-side formats were found only in the longitudinal strip analysis. Were we to apply the conventional criterion ( $\mathrm{p}<.05$, as in the approach taken by Neyman \& Pearson, 1933), the analysis would end here (Balluerka, Gómez, \& Hidalgo, 2005). However, a glance at the data in the contingency table in Figure 2 clearly suggests that the groups are not as similar as the null hypothesis significance test would appear to indicate. In the 7-a-side format, the percentage of moves ending in the lateral strips was evenly distributed between the right- and left-hand strips (essentially in the safety and creation zones), while in the 8-a-side format, a majority of moves ended in the right-hand strip. In other words, the use of pitch space does not appear to be the same in the two game formats.

Larger samples increase the likelihood of detecting significant differences between groups, i.e., they increase the power of the statistical test (Sun, Pan, \& Wang, 2011). Table 2 shows the results for the minimum sample size calculated by GPower.

The analysis shows that for the different levels of statistical power analyzed, the number of moves required to yield potentially significant results would be 569 (for a power of 95\%), 478 (for 90\%), 420 (for 85\%), and 376 (for 80\%).

Given the difficulty of organizing a new round of data collection, we proceeded to simulate an increase in sample size, while conserving the characteristics of the original data. Specifically, we tripled and quadrupled the number of original observations, thereby avoiding any modification of the initial groups. This gave a new number of moves as follows: $144 \times 3=432 \approx 478(90 \%)$ and 420 (85\%); $144 \times 4=576 \approx 569(95 \%)$.

Table 2.

Determination of sample size with a power of $95 \%, 90 \%, 85 \%$, and $80 \%$.

\begin{tabular}{llcccc}
\hline & & $95 \%$ & $90 \%$ & $85 \%$ & $80 \%$ \\
\hline Input: & Effect size $w$ & .2 & .2 & .2 & .2 \\
& $\alpha$ err prob & .05 & .05 & .05 & .05 \\
& Power (1- $\beta$ err prob) & .95 & .90 & .85 & .80 \\
Output & Df & 8 & 8 & 8 & 8 \\
& Noncentrality parameter $\lambda$ & 22.760 & 19.120 & 16.800 & 15.040 \\
& Critical $X^{2}$ & 15.507 & 15.507 & 15.507 & 15.507 \\
& Total sample size & 569 & 478 & 420 & 376 \\
\hline
\end{tabular}

Table 3 compares the results from the original sample with those from the simulation. In the nine comparisons conducted, game format was only significantly associated with the strip in which the offensive moves ended $(p<.05)$. However, when we multiplied the number of observations in the original data sets by three, significant associations were detected between game format and numerous variables, namely, the zone in which moves ended; the proportion of moves ending in the safety, creation, and definition sectors; the strip (general analysis) in which moves ended; and the proportion of moves ending in the left-hand strip. On multiplying the 
number of original observations by four, we additionally detected significant differences in the general analysis of the sector in which moves begun in zone 20 ended. It can be seen that the value of $\chi^{2}$ (and, therefore, its significance) depends on sample size. However, the magnitude of the correlation between the variables, quantified by Cramer's V, is independent of sample size. In other words, it is the same in the original sample and the simulation. This is because the main characteristics of the sample (frequencies, variability, and distribution) were kept constant, despite the increase in observations.

Table 3

Comparison of significance levels and correlation magnitude for the different hypothesis contrasts according to the observational sample used.

\begin{tabular}{lcccccccccc}
\hline Contrast & $\mathrm{n}$ & Pearson $\chi^{2}$ & $\mathrm{p}<$ & Cramer's V & $\mathrm{nx3}$ & $\mathrm{p}<$ & Pearson $\chi^{2}$ & $\mathrm{n} \times 4$ & $\mathrm{p}<$ & Pearson $\chi^{2}$ \\
\hline Zones (overall) & 144 & 10.227 & .249 & .266 & 432 & .001 & 30.680 & 576 & .001 & 40.906 \\
Sector (overall) & 144 & 1.650 & .438 & .107 & 432 & .084 & 4.950 & 576 & .037 & 6.600 \\
Safety sector & 15 & 2.302 & .316 & .392 & 45 & .032 & 6.905 & 60 & .010 & 9.206 \\
Creation sector & 84 & 4.232 & .121 & .224 & 252 & .002 & 12.696 & 336 & .001 & 22.271 \\
Definition sector & 45 & 2.181 & .336 & .220 & 135 & .038 & 6.544 & 180 & .013 & 8.725 \\
Strip (overall) & 144 & 6.677 & .035 & .215 & 432 & .001 & 20.031 & 576 & .001 & 26.707 \\
Left strip & 35 & 2.733 & .255 & .279 & 105 & .017 & 8.199 & 140 & .004 & 10.932 \\
Central strip & 59 & .334 & .846 & .075 & 177 & .606 & 1.002 & 236 & .513 & 1.336 \\
Right strip & 50 & .543 & .762 & .104 & 150 & .443 & 1.628 & 200 & .338 & 2.171 \\
\hline
\end{tabular}

\section{DISCUSSION}

This study had both a practical and a methodological objective. In the first case, we analyzed the use of pitch space as a marker of quality of play to compare the suitability of 7-aside and 8-a-side soccer formats in terms of helping children about to move from the U-10 to the U-12 category to improve their soccer skills. In the second part of the study, we showed that calculating minimum sample size can be a useful tool when designing research based on observational methodology. The aim of this strategy is to achieve a balance between the economy (and greater efficiency) offered by an observational study involving a small sample and the greater likelihood of finding significant results in a study with a larger sample.

\section{Findings with respect to the two formats (7- and 8-a-side)}

Numerous authors have highlighted how the use of space is a key factor in the development of play in soccer (Castelo, 2009; Clemente, Couceiro, Martins, Figueiredo, \& Mendes, 2014; Gréhaigne, 1998). Vales (1998) goes as far as to consider it a functional indicator of play, while Arana, Lapresa, Anguera, and Garzón (2012) use it as a measure of the extent to which 12- to 13year-old soccer players have mastered the game. In the present study, moves initiated in the goal area of the attacking team were used as an indicator of players' capacity to move the ball forward towards the rival goal (Castellano, 2000; Perea, 2008).

In our original analysis, we only observed significant differences in the use of space between the 7-a-side and 8-a-side format when the pitch was analyzed by longitudinal strips. However, when we simulated a three- and fourfold increase in sample size, while maintaining the characteristics of the original data, clear differences emerged between the two formats in relation to a) the zone in which moves initiated in the goal area ended; b) the proportion of moves ending in the safety sector; c) the proportion of moves ending in the creation sector; d) the proportion of moves ending in the definition sector; e) the strip in which moves ended; and $f$ ) the proportion of moves ending in the left strip. In the general analysis of sectors, significant differences $(\mathrm{p}<$.037) were detected between the two formats when the sample size was increased by four, while near-significant differences $(p<.084)$ were detected when it was increased by three.

The proportion of moves ending in each of the nine zones analyzed varied considerably depending on the format. In the 7-a-side format, a majority of moves $(29.9 \%)$ ended in zone 50 (creation sector, central strip), whereas in the 8- 
a-side format, a majority of moves (26\%) ended in zone 60 (creation sector, right strip).

In the sector analysis, most 7-a-side moves ended in the safety sector, whereas most 8 -a-side moves ended in the creation sector. Although this would appear to suggest a greater depth of play in the 8-a-side format, it would be interesting to apply sequential analysis (Bakeman, 1978) to explore whether the more frequent loss of possession seen in the safety sector in 7-a-side games is due to a higher frequency of short actions in this format, in which the less balanced 1-2-3-1 formation makes it easier to find open spaces and create play (Etxeazarra, 2014). In the 7 -a-side format, most moves ended in the central strip, regardless of sector. In addition, there was a clear balance between the number of moves that ended in each of the zones in the two lateral strips. This balance, combined with the higher percentage of moves ending in the central strip, is an argument in favor of the 7-a-side format. The results obtained in both formats are in line with those reported in relation to depth of play in both adult soccer (Castelo, 2009; Mombaerts, 1991; Perea, 2008) and 7-a-side soccer (Ardá, 1998; Ardá \& Anguera, 2000).

In contrast to the above, the more balanced tactical formation characteristic of 8-a-side soccer appears to lead to a higher percentage of moves ending in the right-hand strip, to a lack of balance in terms of the zones in which moves end when considered by strip, and to a disproportionally high presence of zones 50 and 80 , corresponding to the central strip. In this regard, Ardá (1998), in a study of 7-a-side soccer, and Arana (2011), in a study of 7-, 9-, and 11-aside soccer also found that a higher proportion of moves ended in the strip in which they had begun.

\section{Findings with respect to the determination of minimum sample size}

Several factors contribute to the level of significance achieved by statistical tests, one of the most important being sample size (Sedlmeier \& Gigerenzer, 1989). The value of the $\chi^{2}$ statistic, for instance, depends on the number of data points used in its calculation: the greater the number of empirical observations $\left(f_{0}\right)$, the greater the difference that will be obtained in the numerator $\left[\left(f_{o}-f_{e}\right)^{2}\right]$ and the higher the value of $\chi^{2}$ will be, regardless of the number of expected observations $\left(\mathrm{f}_{\mathrm{e}}\right)$. In other words, the value of the contrast statistic is not independent of sample size. Since a higher $\chi^{2}$ value corresponds to a lower significance value, large samples tend to yield more significant differences. By increasing sample size, we reduce standard error and increase statistical power (Sun et al., 2011).

The present study provides a good illustration of the above. Of the nine original comparisons, only one-that of the relationship between game format and strip in which moves ended-proved to be significant at the conventional level of $\mathrm{p}<$ .05. However, direct observation of the percentages for each pitch zone suggested that there were genuine differences between the two formats studied. Hence, we sought to calculate the minimum sample size required to detect significant differences. As the study and data collection had already been completed, this analysis was based on a simulation in which we examined the effect of a three- and four-fold increase in sample size, while maintaining the characteristics of the original data. The result was that the number of significant differences rose from 1 to 6 in the case of the three-fold increase and 7 in the case of the four-fold increase (see Table 3). The only differences that continued to be non-significant were those that also appeared to be similar at first glance.

It should be highlighted that significant differences are not always found when sample size is increased (de la Fuente, Cañadas, Guàrdia, \& Lozano, 2009), as there simply might not be a relationship between variables. Likewise, the relationship might be so weak that an impossibly large sample size would be needed to detect any significant differences. In sum, the procedure is only appropriate when, as in the present study, there is good reason to suspect that the groups being compared are indeed different but that the differences are masked because the study is underpowered (Cohen, 1988, 1990). 


\section{CONCLUSIONS}

The present study had two objectives. The first, of a more practical nature, was to analyze the use of space as a functional indicator of player skills with the broader aim of comparing the suitability of 7 -a-side and 8 -a-side soccer for developing these skills in children about to move up to the U-12 category. The results obtained in relation to both the depth and width of play support the theoretical assumption that the distribution of players on the pitch is more balanced in the 8-a-side format, making it more difficult for players to find open spaces and create play than in the 7-a-side format. This is an important consideration, as players in the age group studied have limited ball skills.

With reference to depth of play, the analysis of the combined results shows that the greatest differences between the two formats occurred in the safety sector (more moves ended here in the 7-a-side format) and in the creation sector (more moves ended here in the 8-a-side format). These differences could be related to the fact that the use of the 1-2-3-1 formation in 7-a-side soccer facilitates the creation of open spaces and movement of the ball upfield. However, this theory needs to be studied in greater detail in future studies.

With respect to width of play, the analysis by longitudinal strip shows that play was practically symmetrical in each of the three sectors (safety, creation, and definition) in the 7-a-side format. This format was associated with better-quality play, since more moves ended in the central strip and the numbers of moves ending in the two lateral strips were similar. In the 8-a-side format, by contrast, there was a clear tendency for moves to end in the right-hand strip. This is probably due to the greater difficulty that players of this age have finding space in which to build an attack due to the 1-3-3-1 formation.

The second objective of this study, which had a methodological root, was to illustrate how determination of minimum sample size can be used to analyze the power of an observational methodology study to detect significant differences between comparison groups. Based on a statistical significance level of $\mathrm{p}<.05$, our original analysis revealed largely insignificant differences between the use of space in 7-a-side and 8 -a-side games, but the percentages in the contingency tables clearly suggested that there were genuine differences between the formats. Given that the power of statistical tests can be increased by increasing the number of observations, we calculated the minimum sample size necessary to detect significant differences. By simulating an increase in sample size without changing the parameters that characterized the original sample, we aimed to strike a balance, or rather compromise, between a small, yet efficient, sample and a large sample that, while offering a greater chance of detecting significant differences, would be unfeasible.

\section{Acknowledgments: \\ We gratefully acknowledge the support of the Spanish Government within the project La actividad fisica y el deporte como potenciadores del estilo de vida saludable. Evaluación del comportamiento deportivo desde metodologías no intrusivas (Secretaría de Estado de Investigación, Desarrollo e Innovación del Ministerio de Economia y Competitividad).}

\section{Conflicts of Interest:}

Nothing to declare.

\section{Funding:}

Spanish Government [DEP2015-66069-P].

\section{REFERENCES}

Anguera, M. T. (2003). La observación. In C. M. Rosset (Ed.), Ejercicios prácticos de evaluación psicológica: concepto, proceso y aplicación en las áreas del desarrollo y de la inteligencia. Madrid: Sanz y Torres.

Anguera, M. T., Blanco-Villaseñor, A., HernándezMendo, A., \& Losada, J. L. (2011). Diseños Observacionales: Ajuste y aplicación en psicología del deporte. Cuadernos de Psicología del Deporte, 11(2), 63-76.

Arana, J. (2011). Adaptando el fútbol al niño de 12-13 años: análisis observacional de la utilización del espacio en las modalidades de fútbol 7, fútbol $9 y$ fútbol 11 (Doctoral Dissertation). Universidad de La Rioja, Logroño.

Arana, J., Lapresa, D., Anguera, M. T., \& Garzón, B. (2012). Adapting football to the child: an application of the logistic regression model in observational methodology. Quality \& Quantity, $47(6)$, 3473-3480. http://doi.org/10.1007/s11135-012-9734-z 
Ardá, A. (1998). Análisis de patrones en fútbol a 7 (Doctoral Dissertation). Universidad de La Coruña, La Coruña.

Ardá, T., \& Anguera, M. T. (2000). Evaluación prospectiva en programas de entrenamiento de fútbol a 7 mediante indicadores de éxito en diseños diacrónicos intensivos retrospectivos. Psicothema, 12(Sup 2), 52-55.

Bakeman, R. (1978). Untangling streams of behavior: Sequential analysis of observation data. In G. P. Sackett (Ed.), Observing Behavior: Data collection and analysis methods (Vol. 2, pp. 6378). Baltimore: University Park Press.

Bakeman, R., Mcarthur, D., \& Quera, V. (1996). Detecting group differences in sequential association using sampled permutations: Log odds, kappa, and phi compared. Behavior Research Methods, Instruments, \& Computers, 28(3), 446-457. http://doi.org/10.3758/BF03200524

Bakeman, R., \& Quera, V. (1996). Análisis de la interacción: análisis secuencial con SDIS y GSEQ. Madrid: RA-MA.

Balluerka, N., Gómez, J., \& Hidalgo, D. (2005). The Controversy over Null Hypothesis Significance Testing Revisited. Methodology, 1(2), 55-70. http://doi.org/10.1027/1614-1881.1.2.55

Blanco-Villaseñor, A., Losada, J. I., \& Anguera, M. T. (2001). Diseños observacionales, cuestión clave en el proceso de la metodología observacional. Metodología de Las Ciencias Del Comportamiento, 3(2), 135-160.

Castellano, J. (2000). Observación y análisis de la acción de juego en el fútbol (Doctoral Dissertation). Universidad del País Vasco, Vitoria.

Castelo, J. (2009). Futebol. Organizaçao dinámica do jogo. Lisboa: Centro de Estudos de Futebol da Universidades Lusófona de Humanidades e Tecnologías.

Clemente, F. M., Couceiro, M. S., Martins, F. M., Figueiredo, A. J., \& Mendes, R. M. (2014). Análise de jogo no Futebol: Métricas de avaliação do comportamento coletivo. Motricidade, 10(1), $14-26$. http://doi.org/10.6063/motricidade.10(1).1517

Cohen, J. (1960). A Coefficient of Agreement for Nominal Scales. Educational and Psychological Measurement, 20(1), 37-46. http://doi.org/10.1177/001316446002000104

Cohen, J. (1988). Statistical power analysis for the behavioral sciences (2nd ed.). Hillsdale, NJ: L. Erlbaum Associates.

Cohen, J. (1990). Things I have learned (so far). American Psychologist, 45(12), 1304-1312. http://doi.org/10.1037/0003-066X.45.12.1304

Costa, I. T., Garganta, J., Greco, P. J., \& Mesquita, I. (2009). Avaliação do desempenho tático no futebol: Concepção e desenvolvimento da grelha de observação do teste 'GR3-3GR'. Revista Mineira de Educação Física, 17(2), 36-64. de la Fuente, E. I., Cañadas, G. R., Guàrdia, J., \& Lozano, L. M. (2009). Hypothesis Probability or Statistical Significance? Methodology, 5(1), 3539. http://doi.org/10.1027/1614-2241.5.1.35

Dupont, W. D., \& Plummer, W. D. (1990). Power and sample size calculations. A review and computer program. Controlled Clinical Trials, 11(2), 116128.

Etxeazarra, I. (2014). Análisis de la respuesta física y del comportamiento motor en competición de futbolistas de categoría alevín, infantil y cadete. (Doctoral Dissertation). Universidad del País Vasco, Vitoria.

Faul, F., Erdfelder, E., Buchner, A., \& Lang, A.-G. (2009). Statistical power analyses using $G^{*}$ Power 3.1: Tests for correlation and regression analyses. Behavior Research Methods, 41(4), 1149-1160. http://doi.org/10.3758/BRM.41.4.1149

Faul, F., Erdfelder, E., Lang, A.-G., \& Buchner, A. (2007). G*Power 3: A flexible statistical power analysis program for the social, behavioral, and biomedical sciences. Behavior Research Methods, $39(2)$,

175-191. http://doi.org/10.3758/BF03193146

Federazione Italiana Giuoco Calcio. (2008). Guida tecnica per le scuole di Calcio. Roma: Settore Giovanile e Scolastico.

Gréhaigne, J. F. (1998). Game systems in soccer from the point of view of coverage of space. In T. Reilly \& A. M. Williams (Eds.), Science and Soccer (p. 316). London: Routledge.

Kerlinger, F. N., \& Lee, H. B. (2001). Investigación del comportamiento. Métodos de Investigación en Ciencias Sociales. Mexico: McGraw-Hill.

Landis, J. R., \& Koch, G. G. (1977). The Measurement of Observer Agreement for Categorical Data. Biometrics, 33(1), 159-174. http://doi.org/10.2307/2529310

Lapresa, D. (2009). Hacia una optimización del modelo de competiciones en fútbol. In II Congreso Internacional de Deportes de Equipo. [Electronic version]. La Coruña: Universidad de La Coruña, Editorial y Centro de Formación Alto Rendimiento.

Lapresa, D., Arana, J., Anguera, M. T., \& Garzón, B. (2013). Comparative analysis of sequentiality using SDIS-GSEQ and THEME: a concrete example in soccer. Journal of Sports Sciences, 31(15), 1687-1695. http://doi.org/10.1080/02640414.2013.796061

Lapresa, D., Arana, J., Garzón, B., Egüen, R., \& Amatria, M. (2008). Enseñando a jugar ‘el fútbol'. Hacia una iniciación coherente. Logroño: Universidad de La Rioja y Real Federación Española de Fútbol.

Martín, Q., Cabero-Morán, M. T., \& de Paz-Santana, Y. del R. (2007). Tratamiento estadístico de datos con SPSS. Prácticas resueltas y comentadas. Madrid: Paraninfo, S.A.

Meléndez, G. (2001). Pautas para la organización de una escuela de fútbol base. In I Jornadas 
Universidad de La Rioja - Federación Riojana de Fútbol. Logroño: Universidad de La Rioja.

Meléndez, G. (2010). ¿Fútbol 8? ¿Por qué? (Inf. Téc.). Madrid: Real Federación Española de Fútbol.

Mombaerts, E. (1991). Football, de l'analyse du jeu à la formation du Joueur. Joinville-le-Pont: Actio.

Neyman, J., \& Pearson, E. S. (1933). On the Problem of the Most Efficient Tests of Statistical Hypotheses. Philosophical Transactions of the Royal Society of London. Series A, 231, 289-337.

Ninín, L., Villalón, G., Terrasa, S., \& Rubinstein, F. (2007). Tamaño muestral y poder estadístico: ¿Para que sirven? Evidencia, 10(5), 148-150.

Perea, A. E. (2008). Análisis de las acciones colectivas en el fútbol de rendimiento (Doctoral Dissertation). Universidad del País Vasco, Vitoria.

Quera, V., Bakeman, R., \& Gnisci, A. (2007). Observer agreement for event sequences: methods and software for sequence alignment and reliability estimates. Behavior Research Methods, 39(1), 39-49.

Santos, F. M., Fernandez, J., Oliveira, M. C., Leitão, C., Anguera, M. T., \& Campaniço, J. (2009). The pivot player in handball and patterns detection Instrument. Motricidade, 5(3), 29-36. http://doi.org/10.6063/motricidade.5(3).193

Sarmento, H., Leitão, J., Anguera, M. T., \& Campaniço, J. (2009). Observational methodology in football:
Development of an instrument to study the offensive game in football. Motricidade, 5(3), 1924. http://doi.org/10.6063/motricidade.5(3).191

Sedlmeier, P., \& Gigerenzer, G. (1989). Do studies of statistical power have an effect on the power of studies? Psychological Bulletin, 105(2), 309-316.

Sun, S., Pan, W., \& Wang, L. L. (2011). Rethinking observed power: Concept, practice, and implications. Methodology: European Journal of Research Methods for the Behavioral and Social Sciences, $\quad 7(3), \quad 81-87$. http://doi.org/10.1027/1614-2241/a000025

Vales, A. (1998). Una propuesta de indicadores tácticos para la optimización de los sistemas de juego en fútbol (Doctoral Dissertation). Universidad de La Coruña, La Coruña.

Vegas, G. (2006). Metodología de enseñanza basada en la implicación cognitiva del jugador de fútbol base (Doctoral Dissertation). Universidad de Granada, Granada.

von Eye, A., \& von Eye, M. (2005). Can one use Cohen's Kappa to examine disagreement? Methodology, 1(4), 129-142. http://doi.org/10.1027/1614-2241.1.4.129

Wein, H. (2006). Developing Youth Football Players. Champaign, Illinois: Human Kinetics. 